\title{
Infection of Phytophthora palmivora from Soil in C ocoa Plantation
}

\author{
Infeksi Phytophthora palmivora dari Tanah Pada Kebun Kakao
}

\author{
A gus Purwantara ${ }^{11}$
}

\begin{abstract}
Summary
Phytophthora palmivora causes serious losses on cocoa in Indonesia and world-wide. The research aimed to assess the potential of soil as source of inocula for Phytophthora diseases in cocoa. Soil samples were baited using a heal thy cocoa pod tissue, and the pathogen was isolated for morphological and molecular identification. Baiting technique was successfully used to detect the presence of $P$. palmivora in soil samples, and this was confirmed by morphological and molecular identification. P. palmivora can be detected in soil in all year around in wet areas indicating that soil is a massive and consistent source of inocula. Surveys conducted on the soil of A mazonian, A melonado and Trinitario blocks of various ages showed that P. palmivora can be found in old and young cocoa blocks, even as young as 3 or 4 years. P. palmivora infection from soil to the pods appears to be mainly through contact or rain splash. Baiting with whole healthy pods exposed at different heights above undisturbed litter and above bare soil showed that the infection still occurred at $100 \mathrm{~cm}$ above the soil, even though it decreased gradually with the height. Infection from litter was not different to that from bare soil, indicating that the litter layer is not acting physically as a shield preventing rain from splashing the inocula up from wet soil to the pods. However, in tests for the possibility of P. palmivora carried through air convection, no pod was found to be infected, suggesting that the pathogen was not carried through convective accend of aerosol droplets from soil surface up to pods in the canopy.
\end{abstract}

\section{Ringkasan}

Phytophthora palmivora menyebabkan kerugian yang besar pada kakao di Indonesia dan di seluruh dunia. Penelitian bertujuan untuk menetapkan potensi tanah sebagai sumber inokulum penyakit Phytophthora pada kakao. Sampel tanah diumpan (baiting) menggunakan jaringan buah kakao sehat, dan patogen diisolasi untuk identifikasi secara morfologis dan molekuler. Teknik baiting berhasil mendeteksi P. palmivora di dalam sampel tanah, dan hasilnya telah dikonfirmasi dengan identifikasi secara morfologis dan molekuler. P. palmivora berhasil dideteksi

1) Peneliti Utama (Principal Scientist); Biotechnology Research Institute for Estate Crops, JI. Taman Kencana 1, Bogor Indonesia. 
di dalam tanah sepanjang tahun di kebun kakao di daerah basah. Hal ini menunjukkan bahwa tanah merupakan sumber inokulum utama dan tetap di perkebunan kakao. Survai pada tanah di pertanaman kakao tipe Amazon, Amelonado dan Trinitario pada berbagai umur tanaman menunjukkan bahwa P. palmivora dapat ditemukan pada tanaman tua atau muda, bahkan pada tanaman umur 3 atau 4 tahun. Infeksi P. palmivora dari tanah ke buah kakao terutama terjadi melalui kontak langsung atau percikan air hujan. Pengumpanan dengan buah utuh yang diletakkan pada berbagai ketinggian di atas serasah atau di atas tanah tanpa serasah menunjukkan bahwa infeksi terjadi pada buah yang diletakkan pada $100 \mathrm{~cm}$ di atas permukaan tanah, meskipun persentasenya berangsur turun dengan meningkatnya ketinggian. Infeksi pada buah yang diletakkan di atas serasah tidak berbeda dengan yang diletakkan di atas tanah tanpa serasah. $\mathrm{H}$ al demikian menunjukkan bahwa lapisan serasah tidak berperan sebagai penghalang bagi percikan air hujan yang membawa inokulum dari tanah ke buah kakao. Namun, dalam uji kemungkinan P. palmivora terbawa oleh konveksi udara, tidak ada satupun buah yang terinfeksi. Hal ini menunjukkan bahwa patogen tidak terbawa oleh tetesan aerosol yang bergerak secara konvektif dari tanah ke buah kakao pada tajuk tanaman.

Key words : Theobroma cacao, pod rot, stem canker, baiting.

\section{INTRODUCTION}

A mong the numerous pathogens of cocoa, Phytophthora spp. cause serious losses. World-wide, average crop losses are about 10 percent, with direct losses of up to 90 percent in wetter regions ( $D$ renth \& Sendall, 2004a; M cM ahon and Purwantara, 2004). L osses of up to 50 percent have been recorded in several plantations in Java (Wardojo, 1992). All parts of cocoa can be affected (Drenth \& Guest, 2004a). Y ield loss occurs through pod rot, whereas tree decline or death occurs through cankers of stem and branch (A braham et al., 2000; Blaha \& Eskes, 2000; Chow dappa, 2000). U nhardened tissues are rapidly killed in seedlings, chupons, flush leaves and cherelles (Chowdappa \& Rohini, 2000). Root system, especially feeding roots, can also be attacked (Opoku \& Wheeler, 1998).
Initially, it was though that pod rot and canker throughout the world were caused by the one species, Phytophthora palmivora. However, eight species of P hytophthora have been isolated from cocoa (M CM ahon \& Purwantara, 2004), with two major species notably $P$. palmivora with a world-wide distribution (Bong et al., 2000; I waro et al., 2000; Lee \& Lum, 2004; Portales, 2004; Sangchote et al., 2004; Thanh et al., 2004) and $P$. megakarya which is restricted to $W$ est A frica (Akrofi \& Opoku, 2000; Opoku et al., 2002; A ppiah et al., 2003). M ost of epidemiology studies was conducted on $P$. megakarya which is the major cause of pod rot in Nigeria and Cameroon and which is also more aggressive than $P$. palmivora (Gregory et al., 1984). Certain parts of Cameroon have particularly high losses to pod rot because of high rainfall and the absence of a dry season. This $P$. megakarya 
may even have slightly different life cycle to $P$. palmivora relying more on root infection for survival while $P$. palmivora relies more on flower cushion or stem infection (Gregory et al., 1984). Pod rot and stem canker occur widely in cocoa plantations in Indonesia. Samples taken from cocoa growing areas consistently indicate the presence of P. palmivora (U mayah \& Purwantara, 2006; Rubiyo et al., 2008).

Detailed studies on $\mathrm{P}$. megakarya in Nigeria revealed that pod rot epidemic started from soil as initiators (Gregory et al., 1984). Soil phase of P. megakarya is important in initiating disease epidemic on cocoa. To adopt the control strategy of attacking a pathogen at the weakest point in its life cycle, the sources of infection from which infections arise in the beginning of epidemic must be identified. There are many sources of infection in cocoa and need to be identified in cocoa plantation in Indonesia as they may not equally important and significant in the epidemic. This paper summarizes research on the potential of soil as source of inoculum for infection on cocoa. Research was conducted in a wet area in W est Java with no distinct dry season in the year.

\section{MATERIALS AND METHODS Detection of Phytophthora palmivora}

A pproximately 5 gram of soil samples were taken from the surface of soil below cocoa tree that consistently showed Phytophthora pod rot or stem canker in Bunisari Estate, W est Java. The samples were individually wrapped with an alu- minium foil and were brought to the laboratory for isolation and identification of the pathogen. Healthy, fully expanded pods were used as baits for isolation of the pathogen. A hole (5 $\mathrm{mm}$ deep) was made on the surface of the pod with a sterile cork borer (diameter $5 \mathrm{~mm}$ ), and soil samples were inserted into the hole. The inoculated pods were then wrapped with moist paper and incubated at room temperature for 5 days. A typical dark brown symptom occurred on the inoculated sites after a few days of incubation indicates the presence of Phytophthora in the soil sample. Subsequently, Phytophthora sp. was isolated from the dark brown symptom using lima bean agar, cultured in the same media for morphological and molecular identification of the pathogen. M orphological identification was based on criteria explained by Erwin \& Ribeiro (1996) and Drenth \& Sendall (2004b). For molecular identification, DNA of the fungus was extracted and amplified using ITS 4 and ITS 5 primers, and the amplified fragments were digested using 3 restriction enzymes, namely Alu I, M sp I, and Taq I as reported before (Cooke et al., 2000; U mayah, 2004; U mayah \& Purwantara, 2006).

\section{Seasonal fluctuation of Phytophthora in soil}

Five sites were chosen in an A mazonian (U pper A mazon Hybrid) cocoa block in Bunisari Estate, W est Java. On each site, ten soil samples was taken regularly from surface of the soil every month and baited using healthy unripened cocoa pods. Percentage of successful baiting was determined 
based on the presence of typical pod rot symptom on the pods.

\section{Phytophthora in soil of various types and age of plantation}

Soil samples were taken from 3 types of cocoa, viz. A mazonian (U pper A mazon Hybrid), A melonado (West African A melonado) and Trinitario (clone DR 1). On each of cocoa type, 3 different ages of plantation were selected and on each plantation, 5 different sites were sampled. Ten soil samples were taken from each site during rainy season, then baited using healthy cocoa pods. Percentage of successful baiting was determined based on the presence of typical pod rot symptom on the pods.

\section{Phytophthora infection from soil}

Phytophthora infection from soil to the pods appears to be mainly through contact or rain splash. Batches of whole heal thy pods were exposed at different heights above undisturbed litter and above bare soil where the litter was removed for a radius of $1 \mathrm{~m}$, in a Trinitario cocoa block. Those pods were put on wire rings attached at a bamboo pole at the height of $0,20,40,60,80$, and 100 above the soil level. The lowest pod was in contact with the soil. The wire rings were attached at the bamboo pole at a distance of $40 \mathrm{~cm}$ from the pole in spiral fashion so that there is no obstruction for rain splash from soil for each pod. Five bamboo poles were erected above undisturbed litter, and another five were above bare soil as replicates, in a gap between tree rows. All in- fested and mummified pods hanging in the tree at a radius of $5 \mathrm{~m}$ from the bamboo poles were removed to ensure there is no infection from the tree canopy. Pods were exposed for one to four days depending on the rain. Pods were renewed if there was no rain after four days. Following rain, pods were brought to the laboratory for incubation in saturated chamber at room temperature, and then scored for infections.

It was hypothesed that Phytophthora inocula were liberated in splash droplets from soil and then carried by air convection to infect the pods hanging on the tree. To test this, healthy pods were hung in special bamboo-framed plastic cages with shields for rain water and water splashed from the soil, but with windows in the lower sides to allow air convection from soil which may carry the inocula on to the pods inside the cages. Cages were set at various heights from ground level, at interval of $0.5 \mathrm{~m}$ up to $3 \mathrm{~m}$. A t each height, 4 cages were set as replicates. Pods were exposed to air convection inside the cage for a week, then pods were brought to the laboratory for incubation in saturated chamber at room temperature, and scored for infections.

\section{RESULTS AND DISCUSSION}

Soil samples were baited using healthy cocoa pods. Dark brown symptom appeared on the surface of cocoa pods, 2-4 days after insertion of soil samples in the pods. Isolation of pathogen from this typical symptom using lima bean agar resulted in an isolate readily produced round based ovoid sporangia with prominent papillae, caducous 
and with a short occluded pedicel typical of P. palmivora (Erwin \& Ribeiro, 1996; Drenth $\&$ Sendall, 2004b).

DNA of the isolate was extracted and amplified using ITS 4 and ITS 5 primers producing a single fragment of approximately $900 \mathrm{bp}$, and the amplified fragments were digested using 3 restriction enzymes (Alu I, Msp I, and Taq I). Digestion of the amplified fragment using enzyme Alu I resulted in fragments of approximately 500 , 160 , and $155 \mathrm{bp}$. Digestion of the amplified fragment using enzyme $M$ sp I resulted in fragments of approximately 500 and 400 bp. Digestion of the amplified fragment using enzyme Taq I resulted in fragments of approximately $300,280,150$, and 100 bp (Figure 1). The result of this molecular identification confirmed the result of morphological identification that the isolate is P. palmivora (U mayah \& Purwantara, 2006). The presence of $P$. palmivora in soils of cocoa plantations has been reported before and the pathogen capable of infecting other parts of cocoa plant such as pods, stems, cherelles, leaves and roots (Purwantara, 2003; Purwantara et al., 2004; Umayah \& Purwantara, 2006; Umayah et al., 2007; Rubiyo et al., 2008).

In these experiments, healthy cocoa pod tissue has been used not only as bait for soil samples but also as a selective medium. Baiting technique has been successfully used to detect the presence of $P$. palmivora in soil samples without ambiguity as positive samples always produce distinct symptom on the pods. In most cases, macroscopic symptoms with/without microscopic examination of the sporulating symptoms gave adequate identification of the pathogen in
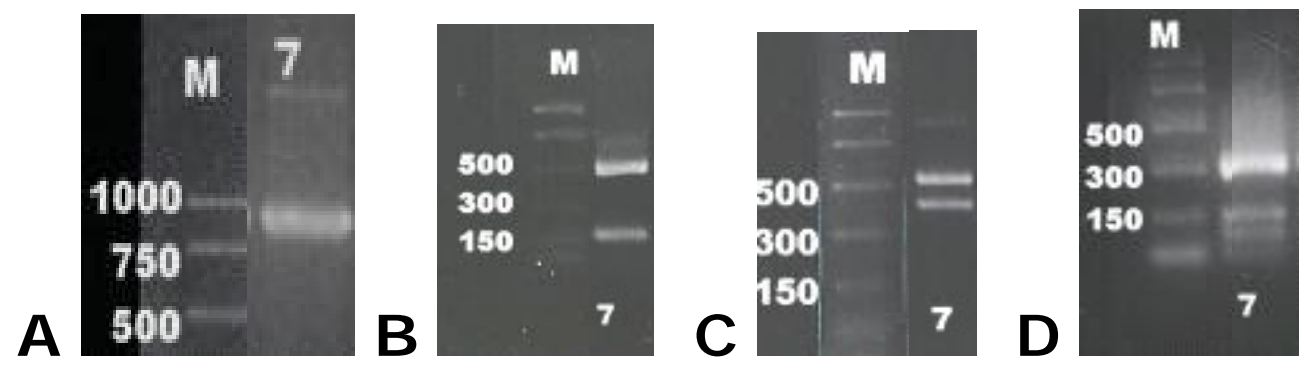

Figure 1. Single DNA fragment ( $\pm 900 \mathrm{bp}$ ) amplified from DNA of Phytophthora palmivora isolates using primers ITS 4 and ITS 5 (A). Fragments of $\pm 500,160$, and $155 \mathrm{bp}$ as results of digestion of the amplified fragment using enzyme Alu I (B); fragments of \pm 500 and $400 \mathrm{bp}$ as results of digestion of the amplified fragment using enzyme Msp I (C); fragments of $\pm 300,280,150$, and 100 bp as results of digestion of the amplified fragment using enzyme Taq I (D); $M=$ marker; 7 = Phytophthora palmivora isolate.

Gambar 1. Fragmen DNA tunggal ( \pm 900 bp) hasil amplifikasi DNA isolat Phytophthora palmivora dengan primer ITS 4 and ITS 5 (A). Fragmen ukuran $\pm 500,160$, dan 155 pb sebagai hasil digesti dengan enzim Alu I (B); fragmen ukuran \pm 500 dan 400 pb sebagai hasil digesti dengan enzim Msp I (C); fragmen ukuran $\pm 300,280,150$, dan 100 pb sebagai hasil digesti dengan enzim Taq I (D); $M=$ marker; 7 = isolat Phytophthora palmivora. 
soil samples. A s selective medium, cocoa pods have been used to detect and isolate the pathogen to make pure cultures without incorporation of antibiotics.

In baiting surface soil monthly over the year, it was found that the percentage of successful baiting varied greatly with the month, mostly ranging from $50 \%$ to $80 \%$, except for $M$ ay (30\%) and September (20\%) (Figure 2). Rainfall occurred throughout the year with the lowest in July $(90 \mathrm{~mm})$. The lowest percentage of successful baiting did not coincide with the lowest monthly rainfall. It seems that in an area without dis- tinct dry months, P. palmivora propagules can be found all year around. This is in contrast with previous report in Nigeria where $P$. megakarya propagules decreased very rapidly towards the end of the rains with very few positive isolation from dry soil, but isolations were successful again in the wetter season suggesting that multiplication had occurred in the soil (Ward \& Griffin, 1981). In the dry season, the pathogen may survive as mycelium in infected roots, as chlamydospores or as encysted zoospores. However, this needs to be examined.

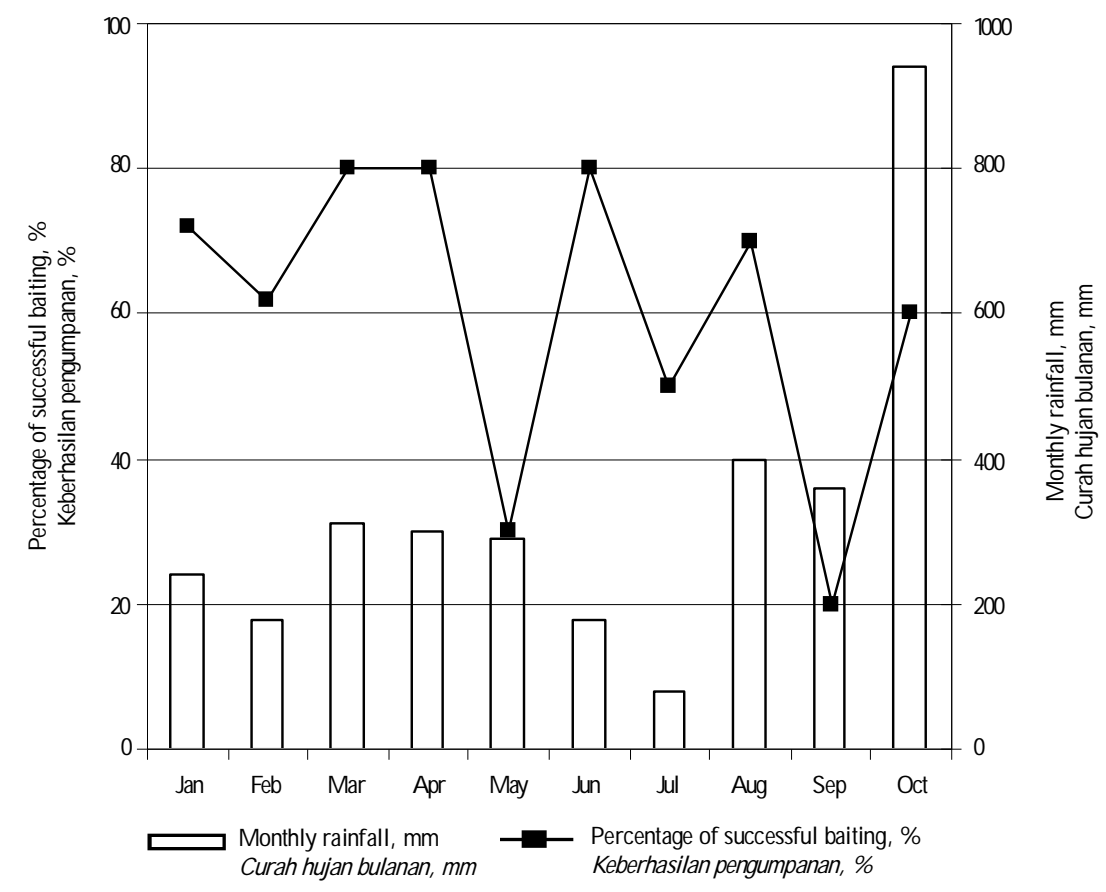

Figure 2. Percentage of successful baiting of soil samples collected monthly at Bunisari Estate, plotted against monthly rainfall.

Gambar 2. Persentase keberhasilan pengumpanan sampel tanah yang dikumpulkan dari Kebun Bunisari dihubungkan dengan curah hujan bulanan. 
Surveys were conducted on the soil of A mazonian, A melonado and Trinitario blocks of various ages to determine how quickly the soil population of $P$. palmivora builds up. The surveys were conducted during the rainy season. Soil samples were taken from each block and were baited using heal thy green pods. There was no relation between the percentage of positive baiting and the age of the plantations. Y oung plantations as well as old plantations gave high positive baiting of $P$. palmivora from soil (Table 1). Surprisingly, A melonado block as young as 3 years and Trinitario block (4 years) showed high positive baiting (76\% and $90 \%$, respectively). The presence of the pathogen in the young block appears to be associated with previous plantings as those two blocks are rehabilitation areas. This suggests that soil is an important source of primary inoculum for disease epidemics on cocoa, as reported in Papua N ew Guinea (K onam, 1999; Konam et al., 2000, K onam \& Guest, 2004). It can also be noted that all of the Trinitario blocks gave the high- est positive baiting. This possibly related with the highest incidence of pod rot and canker on this cocoa type as reported before (Pawiro-soemardjo \& Purwantara, 1992). Blaha et al. (2000) also reported that Trinitario is more susceptible to pod rot than A melonado and A mazonian types in Papua New Guinea.

To assess the amount of infection from the soil in a cocoa plantation, healthy pods were exposed to natural splash above bare soil and above litter. In 10 tests conducted during A ugust-N ovember, 300 pods were exposed above bare soil and 300 pods above litter. Eight pods above bare soil and 5 pods above litter were discounted because of "preinfection". A lmost all of pods laid on the surface of soil were infected (Table 2, Figure 3). The infection decreased gradually with the height. Infection still occurred at $100 \mathrm{~cm}$ above the soil. A pparently, the soil litter only slightly reduced the number of infected pods. These facts suggest that the litter layer is not effectively acting as a shield preventing rain from

Table 1. Baiting of Phytophthora palmivora in the soil taken from cocoa plantation with various ages of plants

Tabel 1. Pengumpanan Phytophthora palmivora dari sampel tanah yang diambil dari kebun kakao dengan berbagai umur tanaman

\begin{tabular}{cccc}
\hline $\begin{array}{c}\text { Cocoa types } \\
\text { Tipe kaka0 }\end{array}$ & $\begin{array}{c}\text { Age (year) } \\
\text { U mur (tahun) }\end{array}$ & $\begin{array}{c}\text { Number of samples } \\
\text { J umlah sampel }\end{array}$ & $\begin{array}{c}\text { Percentage of infection } \\
\text { Persentase infeksi }\end{array}$ \\
\hline A mazonian & 15 & 50 & 72 \\
& 17 & 50 & 72 \\
A melonado & 20 & 50 & 82 \\
& 3 & 50 & 76 \\
Trinitario & 13 & 50 & 60 \\
& 18 & 50 & 70 \\
& 4 & 50 & 90 \\
& 10 & 50 & 90 \\
\hline
\end{tabular}


Table 2. Percentage of Phytophthora palmivora infection on whole pod baits placed at different height above bare soil and litter

Tabel 2. Persentase infeksi Phytophthora palmivora pada umpan buah utuh yang ditempatkan pada berbagai ketinggian di atas tanah dan serasah

\begin{tabular}{ccc}
\hline $\begin{array}{c}\text { Height of pods, cm } \\
\text { Ketinggian buah, cm }\end{array}$ & $\begin{array}{c}\text { Bare soil, \% } \\
\text { Tanah, \% }\end{array}$ & $\begin{array}{c}\text { Litter, \% } \\
\text { Serasah, \% }\end{array}$ \\
\hline 0 & $50(100)$ & $48(96)$ \\
20 & $32(64)$ & $30(60)$ \\
40 & $23(46)$ & $18(36)$ \\
60 & $18(36)$ & $11(22)$ \\
80 & $15(30)$ & $11(22)$ \\
100 & $12(24)$ & $11(22)$ \\
\hline Percentage of infection of all pods & $150(50)$ & $129(43)$ \\
\hline Persentase infeksi dari seluruh buah & &
\end{tabular}

Keterangan (N otes) : J umlah buah, Persentase (No. of pods, Percentage).

splashing the spores from wet soil up to the pods. Similar result was reported from Brazil where three species of Phytophthora viz. $P$. capsici, P. palmivora and P. citrophthora involved (Pereira, 1992). However, the result is different with the report from $\mathrm{Ni}$ geria, where P. megakarya infection over bare soil $(23.7 \%)$ was significantly higher than over leaf litter (4.5\%) (M addison \& Griffin, 1981). This is in accordance with Gregory's theory that $P$. palmivora may have slightly different life cycle to $P$. megakarya (Gregory et al., 1984).

Henry (1977) reported the infection of whole pod baits at 30 and $60 \mathrm{~cm}$ above soil, but not at $90 \mathrm{~cm}$ in J amaica. However, infection still occurred on baits at $100 \mathrm{~cm}$ above soil in this experiment. In third experiment in October, all baits were infected on bare soil as well as on litter. Possibly, during stormy rain, drips of rain strike the wet soil and generate splash droplets which carry surface water containing P. palmivora inocula upwards to infect the baits at a height of $100 \mathrm{~cm}$.
In 20 tests for the presence of $P$. palmivora through air convection during rainy season, a total of 560 pods were exposed. However, no pod was found to be infected with P. palmivora, indicating that the pathogen was not dispersed by air convection. Gregory et al. (1984) proposed a hypothetical disease cycle for $P$. megakarya in Nigeria in which the pathogen is carried through convective accent of aerosol droplets from soil surface up to pods in the canopy. It seems that the results from this experiment were not in support to the proposed disease cycle for P. megakarya. Possibly, $P$. palmivora behaves slightly different to $P$. megakarya in Nigeria.

M ulching in its broadest sense should be re-examined with the aim of preventing splash from the ground. The lack of significant suppression on the use of litter in this experiment was attributed to litter itself might act as source of inoculum as reported elsewhere. Previous results showed that $P$. palmivora was isolated from organic debris in the litter layer (Purwantara, 2003). 


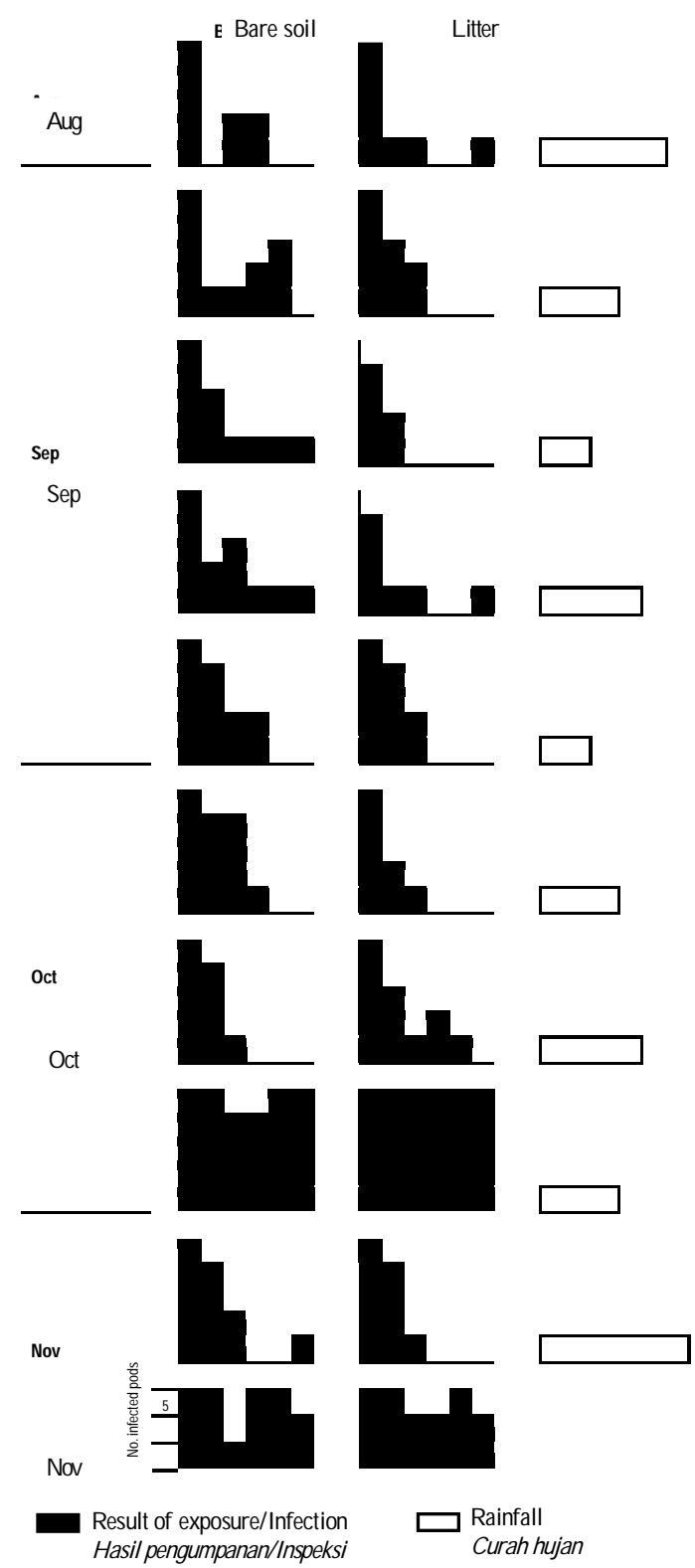

Figure 3. Results of exposure of cocoa pods over bare soil and over litter, with the rainfall for each exposure, during 10 periods. Pods were attached at $0,20,40,60,80$ and $100 \mathrm{~cm}$ above ground level, five pods at each height. Solid squares indicate pod infection.

Gambar 3. Hasil pengumpanan buah kakao di atas tanah dan di atas serasah, dengan curah hujan pada setiap pengumpanan, selama 10 kali pengumpanan. Buah diletakkan pada 0, 20, 40, 60, 80 dan $100 \mathrm{~cm}$ di atas permukaan tanah, lima buah untuk setiap perlakuan. Kotak penuh menunjukkan infeksi pada buah. 
Ward \& Griffin (1981) also obtained the similar results in N igeria. However, mulching might be useful in preserving soil moisture or providing organic matter. In Papua $\mathrm{N}$ ew Guinea, the use of mulches can promote decomposition of litter which in turn can decrease the rate of infection (K onam $\&$ Guest, 2002).

The recommended control method is removal and burial of diseased pods at regular interval, improved drainage, and pruning of cocoa and shade trees especially in the rainy season, and fungicide application such as copper, metalaxyl, or mancozeb (W ardojo, 1992; Sri-Sukamto \& Pujiastuti, 2004; Sri-Sukamto, 2008). Diseased pods should be removed and buried at the depth of $30 \mathrm{~cm}$ from soil surface, and within a few months the pods should be decomposted and become organic fertilizer which improves soil fertility. How ever this practice raises some questions whether the inocula of $P$. palmivora are still viable. In this experiment, it was shown that inocula of $P$. palmivora can be found all year around in the soil. The data indicates that soil is a massive and consistent source of inocula. If the inocula still active in decomposted pods, burying diseased pods in the cocoa plantations can be preserving inocula in the soil. In order to limit the incidence and severity of diseases, effective management strategies are required, including avoiding infection through basic hygiene, improving soil health, and improve drainage and irrigation (Drenth \& Guest, 2004b). The ultimate sanitation method would be removal of diseased pods out of plantations as sug- gested in early days by Turner (1965). However, this method is impractical and also the diseased pods are useful source of organic matter to improve soil fertility. The best solution would be composting the diseased pods properly using commercially available decomposer so that the temperature will increase up to more than $60^{\circ} \mathrm{C}$ during decomposition and will kill P. palmivora. Trichoderma spp. has been used as biological control for Phytophthora diseases on cocoa (Sri-Sukamto, 2008). The use of Trichoderma spp. -based decomposer would be benefit for decomposition of diseased pods as this will eliminate $P$. palmivora inocula through both biofungicidal action and increased temperature in the compost. Also, animal manure compost could be added into the soil, as the compost increases soil organic matter, total biological activity, and populations of antagonistic actinomycetes, bacteria, and fungi (A ryantha et al., 2000). Plantation hygiene, if implemented rigorously and consistently, can significantly reduce diseases pressure in plantation and, in some cases, may be all that is required to manage P hytophthora diseases (Guest, 2004).

\section{CONCLUSIONS}

Soil is an important source of primary inoculum of $P$. palmivora for disease epidemics on cocoa. The pathogen can be found all year around, and therefore suppression of the pathogen in the soil becomes an essential component of an integrated disease management package. 


\section{ACK NOW LE D GE MENTS}

The author wishes to thank directors of PT Perkebunan N usantara VIII (formerly PTPN XIII) and managers of Bunisari Estate for permission to carry out the research and to M r. Didin Syaerudin, M r. Rachmat U mar and M r. M amak Suryani for technical assistances.

\section{REFERENCES}

A braham, K., N.R. Vikraman, V.K. M allika \& S. Prasankumariamma (2000). Status of research on cocoa diseases in Kerala A gricultural U niversity. Proc. National Seminar on Cocoa Development in India: Problems and Prospects. Trichur, India, 84-92.

A krofi, A.Y . \& I. Y . O poku (2000). M anaging Phytophthora megakarya pod rot disease: the Ghana experience. p. 7883. In: Bong, C.L., C.H. Lee \& F.S. Shari (Eds.). P roceedings INCOPED 3rd International Seminar 2000. Kinabalu, M alaysia.

Appiah, A.A.; J. Flood; P.D. Bridge \& S.A. A rcher (2003). Inter- and intraspecific morphometric variation and characterization of Phytophthora isolates from cocoa. Plant Pathology, 52, 168-180.

A ryantha, I.P.; R. Cross \& D.I. Guest (2000). Suppression of Phytophthora cinnamomi in potting mixes amended with uncomposted and composted animal manures. Phytopathology, 90, 775-782.

Blaha, G. \& A.B. Eskes (2000). Field evaluation of Phytophthora pod rot and stem canker incidence. p. 118-119. In: Eskes, A.B., J.M.M. Engels \& R.A. Lass (Eds.). Working Procedures for Cocoa Germaplasm Evaluation And Se- lection. International Plant Genetic Resources Institute, Rome, Italy.

Blaha, G., R. Dufeu \& Y. Efron (2000). Screening of international and experimental local clones and progenies for resistance/susceptibility to Phytophthora by detached pod inoculation in Papua N ew Guinea. p. 64-69. In: Bong, C.L.; C.H. L ee \& F.S. Shari (Eds.). Proceedings INCOPED 3rd International Seminar 2000. Kinabalu, M alaysia.

Bong, C.L.; T.C. Chong; K.L. Lim \& G.T. Lim (2000). Integrated crop management of cocoa clonal plantings for higher productivity and efficiency of crop protection in Sabah, M alaysia. $p$. 123-142. In: Bong, C.L.; C.H. Lee \& F.S. Shari (Eds.). Proceedings INCOPED 3rd International Seminar 2000. Kinabalu, M alaysia.

Chowdappa, P. (2000). An assessment of pathological research at $C$ entral Plantation Crops Research Institute and current research priorities. Proceedings $\mathrm{Na}$ tional Seminar on Cocoa Development in India: Problems and Prospects. Trichur, India, 93-108.

Chowdappa, P. \& I. Rohini (2000). Status of research on integrated management of cocoa diseases in India. p. 84-102. In: Bong, C.L.; C.H. Lee \& F.S. Shari (Eds.). Proceedings INCOPED 3rd International Seminar 2000. Kinabalu, $M$ alaysia.

Cooke, D.E.L.; A. Drenth; J. M. Duncan; G. Wagels \& C.M. Brasier (2000). A molecular phylogeny of Phytophthora and related 0 omycetes. F ungal $G$ enetics and Biology, 30, 17-32.

Drenth, A. \& B. Sendall (2004a). Economic impact of Phytophthora diseases in Southeast A sia. p. 10-28. In : Drenth, 
A. \& D.I. Guest (Eds.). Diversity and $M$ anagement of Phytophthora in Southeast Asia. ACIAR, Canberra, A ustralia.

Drenth, A \& B B. Sendall (2004b). I solation of Phytophthora from infected plant tissue and soil, and principles of species identification. p. 94-102. In : Drenth, A. \& D.I. Guest (Eds.). Diversity and $M$ anagement of Phytophthora in Southeast Asia. ACIAR, Canberra, A ustralia.

Drenth, A \& D.I. Guest (2004a). Phytophthora in the tropics. p. 30-41. In : Drenth, A. \& D.I. Guest (Eds.). Diversity and $M$ anagement of Phytophthora in Southeast Asia. ACIAR, Canberra, A ustralia.

Drenth, A.\& D.I. Guest (2004b). Principles of Phytophthora disease managemant. p.154-160. In : Drenth, A.\& D.I. Guest (Eds.). Diversity and M anagement of P hytophthora in Southeast Asia. ACIAR, Canberra, A ustralia.

Erwin, D.C. \& O.K. Ribeiro (1996). Phytophthora Diseases Worldwide. A PS Press M innesota.

Gregory, P.H.; M .J. Griffin; A.C. M addison \& M.R. Ward (1984). Cocoa black pod: a reinterpretation. Cocoa G rower's Bulletin, 35, 5-22.

Guest, D.I. (2004). Nursery practices and orchard management. p. 161-166. In : Drenth, A. \& D.I. Guest (Eds.). Diversity and $M$ anagement of Phytophthora in Southeast Asia. ACIAR, Canberra, A ustralia.

Henry, C.E. (1977). Primary sources of Phytophthora palmivora (Butl.) Butl. inoculum in Jamaica and methods of control. Proceedings 5th International
Cocoa Research Conference, Ibadan, Nigeria 1975, 388-396.

Iwaro, A.D.; T.N. Sreenivasan; D.R. Butler, J.M. Thevenin; V. M ooleedhar; F. Bekele; O. Sounigo; P. U maharan \& A.B. Eskes (2000). Strategy for germplasm enhancement at Cocoa Research U nit, Trinidad. p. 22-28. In: Eskes, A.B.; J.M.M. Engels \& R.A. $L$ ass (Eds.). Working Procedures for Cocoa Germaplasm Evaluation and Selection. International Plant Genetic Resources Institute, Rome, Italy.

Konam, J.K. \& D.I. Guest (2002). Leaf litter mulch reduces the survival of Phytophthora palmivora under cocoa trees in Papua N ew Guinea. Australian Plant Pathology, 31, 381-383.

Konam, J.K. \& D.I. Guest (2004). Role of flying beetles (Coleoptera: Scolytidae and $\mathrm{N}$ itidulae) in the spread of P hytophthora pod rot of cocoa in papua N ew Guinea. Australasian Plant P athology, 33, 5559.

K onam, J.K. (1999). Integrated M anagement of Phytophthora palmivora Diseases of cocoa in Papua New Guinea. PhD. Thesis. The U niversity of M elbourne, Victoria, A ustralia.

Konam, J.K.; D.I. Guest \& G. Blaha (2000). Role of beetles (Coleoptera: Scolytidae and Nitidulidae) as vectors of Phytophthora palmivora diseases of cocoa in Papua N ew Guinea. p. 7177. In: Bong, C.L.; C.H. Lee \& F.S. Shari (Eds.). Proceedings INCO PED 3rd International Seminar 2000. Kinabalu, M alaysia.

Lee, B.S. \& K.Y. L um (2004). Phytophthora diseases in $M$ alaysia. p. 60-69. In : Drenth, A. \& D.I. Guest (Eds.). Di- 
versity and $M$ anagement of Phytophthora in Southeast Asia. ACIAR, Canberra, A ustralia.

M acM ahon, P.J. \& A. Purwantara (2004). Phytophthora on cocoa. p. 104-115. In : D renth, A \& \& D.I. Guest (Eds.). Diversity and Management of Phytophthora in Southeast Asia. ACIAR, Canberra, A ustralia.

Maddison, A.C. \& M .J. Griffin (1981). Detection and movement of inoculum. p. 62-74. In : Gregory P.H. \& A.C. $M$ addison (Eds.). E pidemiology of Phytophthora on cocoa in Nigeria. CMI, Kew, England.

Opoku, I.Y . \& B.E.J. Wheeler (1998). Survival of Phytophthora palmivora and Phytophthora megakarya on and in roots of cocoa seedlings. Cocoa Growers Bulletin, 51, 33-41.

Opoku, I.Y.; A.Y. Akrofi \& A.A. Appiah (2002). Shade trees are al ternative hosts of the cocoa pathogen, Phytophthora megakarya. Crop Protection, 21, 629634.

Pawirosoemardjo, S. \& A . Purwantara (1992). Laju infeksi dan intensitas serangan Phytophthora palmivora (Butl.) Butl. pada buah dan batang beberapa varietas kakao. M enara Perkebunan, 60, 67-72.

Pereira, J.L. (1992). Cocoa and its pathogens in the region of origin: a continued risk. p. 13-30. In : Keane P.J. \& C.A.J. Putter (Eds.). Cocoa Pest and Disease Management in Southeast Asia and Australasia. FA O, Rome, Paper No. 112.

Portales, L.A. (2004). Phytophthora diseases in the Philippines. p. 90-93. In : Drenth, A. \& D.I. Guest (Eds.). Diversity and $M$ anagement of $P$ hytoph- thora in Southeast Asia. ACIAR, Canberra, A ustralia.

Purwantara, A . (2003). Epidemilogy and control of P hytophthora diseases of cocoa in Java, Indonesia. 8th International Congress of Plant Pathology, Christchurch, N ew Zeal and, 2-7 February 2003. p. 353

Purwantara, A.; D. M anohara \& J.S. Warokka (2004). Phytophthora diseases in Indonesia. p. 70-76. In : Drenth, A.\& D.I. Guest (Eds.). Diversity and $M$ anagement of Phytophthora in Southeast Asia. ACIAR, Canberra, A ustralia.

Rubiyo; A. Purwantara; Sri-Sukamto \& Sudarsono (2008). I solation of indigenous P hytophthora palmivora in Indonesia, their morphological and pathogenicity characterizations. Pelita Perkebunan, 24, 35-48.

Sangchote, S.; S. Poonpolgul; R. Sdoodee; M , K anjanamaneesathian; T. Baothong \& P. L umyong (2004). Phytophthora diseases in Thailand. p. 77-82. In : Drenth, A. \& D.I. Guest (Eds.). Diversity and $M$ anagement of Phytophthora in Southeast Asia. ACIAR, Canberra, A ustralia.

Sri-Sukamto \& D. Pujiastuti (2004). Keefektifan beberapa bahan pengendali penyakit busuk buah kakao Phytophthora palmivora. Pelita Perkebunan, 20, 132142.

Sri-Sukamto (2008). Pengendalian penyakit. p 154-169. In : Wahyudi T.; T.R. Panggabean \& Pujiyanto (Eds.). Panduan Lengkap Kakao. Managemen Agribisnis dari Hulu hingga Hilir. Penebar Swadaya, J akarta.

Thanh, D.V.T.; N.V. V ien \& A. Drenth (2004). Phytophthora diseases in Vietnam. 
p. 83-89. In : Drenth, A. \& D.I. Guest (Eds.). Diversity and $M$ anagement of Phytophthora in Southeast Asia. ACIAR, Canberra, A ustralia.

Turner, P.D. (1965). Behaviour of Phytophthora palmivora in soil. Plant Disease Reporter, 49, 135-137.

Umayah, A.\& A. Purwantara (2006). Identifikasi isolat Phytophthora asal kakao. M enara Perkebunan, 74, 76-86.

Umayah, A. (2004). Analisis Keragaman Genetik Phytophthora palmivora Penyebab Busuk Buah Pada Kakao di Indonesia. PhD. Thesis. Bogor A gricultural University, Bogor, Indonesia. $120 \mathrm{pp}$.

U mayah, A.; M.S. Sinaga; S. Sastrosumarjo; S.M. Sumaraw \& A. Purwantara (2007). Keragaman genetik isolat Phytophthora palmivora dari tanaman kakao di Indonesia. Pelita Perkebunan, 23, 129-138.
W ard, M.R. \& M.J. Griffin (1981). Soil phase of cocoa Phytophthora. p. 50-61. In : Gregory P.H.\& A.C. M addison (Eds. ). E pidemiology of Phytophthora on Cocoa in Nigeria. CMI, Kew, England.

Wardojo, S. (1992). M ajor pests and diseases of cocoa in Indonesia. p. 63-77. In : Keane P.J.\& C.A.J. Putter (Eds.), Cocoa Pest and Disease M anagement in Southeast Asia and Australasia. FA O, Rome, Paper No. 112. 